\title{
Isegoría cumple 30 años y despide polifónicamente a Javier Muguerza
}

Al tener una periodicidad semestral, Isegoría cumple sus primeras tres décadas con este número 60 , donde se publican los textos de las vigésimo-sextas Conferencias Aranguren, un ciclo de conferencias ideado al mismo tiempo que la revista por Javier Muguerza cuando fungió como primer Director del IFSCSIC y de Isegoría. El formato de las Conferencias pretende ir adaptándose a los nuevos tiempos y por de pronto ha cobrado la forma del diálogo entre dos generaciones, representadas en este caso por Javier Echeverría y Remedios Zafra, quienes han ganado sendos premios Anagrama de Ensayo, en 1995 y 2017 respectivamente.

Javier Echeverría ha sido distinguido además en su dilatada trayectoria con otros galardones académicos como el Premio de Humanidades otorgado por la UNAM o el Eusko Ikaskuntza, teniendo asimismo en su haber el primer premio Euskadi de investigación en Humanidades y el Premio Nacional de Ensayo por Los Señores del Aire: Telépolis y el tercer entorno, tercera entrega de una trilogía que comienza con Telépolis y continúa con Cosmopolitas domésticos. También ha sido Director del Instituto de Filosofía, que ahora dirige Concha Roldán.

¿Fin de la intimidad? es la sugestiva interrogante que viene a englobar ambas Conferencias. Como a cualquiera se le alcanza, nuestra intimidad está saltando por lo aires, y lo está haciendo mediante una voladura descontrolada de la que somos cooperadores necesarios, al compartir en las redes asuntos confidenciales que antes únicamente conocían nuestros allegados más próximos, un sinfín de datos que luego son susceptibles de verse malversados por intere- 
ses comerciales o políticos. Nuestras fotos en Facebook, nuestros comentarios en Twitter, nuestras búsquedas en Google y nuestras compras en Amazon van perfilando nuestro daguerrotipo cibernético. Estos rasgos delatan nuestra personalidad y los exhibimos voluntariamente, sin que ningún detective o pirata informático tenga que hacer nada muy sofisticado para obtenerlos. Corren malos tiempos para nuestra privacidad, tan expuesta en los foros públicos, porque todos contribuimos a abrir de par en par las ventanas de nuestra ciudadela interior. El tema no puede ser más relevante, toda vez que moldea nuestro presente, cincela nuestro futuro e incluso contribuye a reescribir nuestro pasado.

Seguidamente se brinda un testimonio de apertura temática, puesto que la parte monográfica del número versa sobre La fenomenología del dolor y alguien podría preguntarse si ese rótulo se ajusta cabalmente al del perfil de una revista sobre filosofia moral y política. La presentación de Ariela Battán Horenstein debía cumplir con el objetivo de no dejar dudas a este respecto. Junto a los textos recibidos mediante la convocatoria publicitada en su día, la sección de Documentos brinda un texto debido a Paul Riceur acerca del sufrimiento y el dolor.

El Consejo de Redacción se ha renovado parcialmente. Debe agradecerse a quienes lo abandonan por uno u otro motivo el servicio prestado y dar a los recién designados la más cordial de las bienvenidas. Entre los primeros están José Francisco Álvarez, Sonia Arribas, Javier Echeverría y Juan Carlos Velasco, mientras que Elena Cantarino, Ana De Miguel, Gerardo López Sastre y Armando Menéndez se integran el equipo compuesto por Roberto R. Aramayo, Txetxu Ausín, Fernando Bayón, Carmen González Marín, Salvador Mas, Javier Muguerza, Eulalia Pérez Sedeño, Concha Roldán, Cristina Sánchez y Nuria Sánchez Madrid, quien ha oficiado como Secretaría de Redacción durante los últimos cuatro años.

P.S.: El 10 de abril, cuando este número estaba ya en imprenta, ha fallecido Javier Muguerza, fundador y primer director de la revista que no hubiera sido posible sin su empeño. "Gero arte, Javier" es el título que hemos puesto al apartado de informaciones donde se recogen distintos testimonios que configuran una despedida coral a Javier Muguerza, cuyo pensamiento supo representar el espíritu de concordia que presidió la transición política española. Está previsto rendir un homenaje a su memoria, que tendrá lugar en la Residencia de Estudiantes, el próximo 18 de septiembre del presente año. 